\title{
PENINGKATAN KESADARAN HUKUM MASYARAKAT DALAM \\ MEMAHAMI PERBEDAAN TINDAK PIDANA PENIPUAN DAN PENGGELAPAN DI KELURAHAN PAGAMBIRAN AMPALU NAN XX
}

\section{Oleh:}

1) Julaiddin, S.H., M.H, ${ }^{2)}$ Sahnan Sahuri Siregar, S.H., M.H, ${ }^{3)}$ Rangga Prayitno, ${ }^{4)}$ J. Sam Miekhel

\author{
1) 2) Dosen Universitas Ekasakti \\ ${ }^{3)}$ Pascarsarjana Universitas Ekasakti \\ ${ }^{4)}$ Fakultas Hukum Universitas Ekasakti
}

\section{BAB I}

\section{PENDAHULUAN}

\subsection{Latar Belakang Kegiatan}

Perkembangan kehidupan masyarakat khususnya di bidang ekonomi dan bisnis melahirkan berbagai perilaku yang dapat merugikan masyarakat itu sendiri. Perkembangan perilaku tersebut juga melahirkan berbagai bentuk atau modus kejahatan, sebagian perbuatan tersebut sudah di atur dalam hukum pidana dan sebagian lagi masih berada dalam wilayah abu-abu atau grey area, artinya dianggap perbuatan hukum perdata semata walaupun sebenarnya perbuatan tersebut telah menimbulkan kerugian bagi sebagian masyarakat. Dalam kajian kriminologi, keadaan ini telah melahirkan proses yang disebut kriminal, sedangkan dalam ilmu hukum pidana keadaan ini telah menimbulkan pidana khusus.

Salah satunya adalah tindak pidana penipuan dan penggelapan. Istilah penipuan dan penggelapan memiliki pengertian yang berbeda tipis, sehingga 
sering disalah artikan oleh masyarakat atau salah pada penempatannya. Meski terlihat mirip, namun sejatinya kedua tindak pidana tersebut memiliki unsurunsur yang berbeda.

Motivasi kedua istilah itu sama-sama ingin memiliki "benda" (barang) milik orang lain, baik sebagian maupun seluruhnya, namun secara melawan hukum. Perbedaannya adalah pada masalah cara bagaimana barang tersebut dimiliki. Dalam penipuan, benda itu dimiliki secara melawan hukum, sedangkan dalam penggelapan upaya memiliki itu dilakukan melalui suatu dasar perbutan yang sah. Penipuan dan penggelapan merupakan tindak pidana yang diatur dalam KUHP.

Dalam KUHP, tindak pidana penipuan diatur dalam Pasal 378 KUHP, sedangkan tindak pidana penggelapan diatur Pasal 372 KUHP. Motif kedua tindak pidana tersebut berbeda satu sama lain. Tindak pidana penipuan bertujuan untuk mendapatkan keuntungan, dengan mendapatkan barang, diberikan utang, maupun dihapus utangnya. Orang yang melakukan tindak pidana penipuan diancam penjara maksimal empat tahun. Pasal 378 KUHP selengkapnya berbunyi sebagai berikut: Barang siapa dengan maksud untuk menguntungkan diri sendiri atau orang lain secara melawan hukum, dengan memakai nama palsu atau martabat palsu, dengan tipu muslihat, ataupun rangkaian kebohongan, menggerakkan orang lain untuk menyerahkan barang sesuatu kepadanya, atau supaya memberi utang maupun menghapuskan piutang, diancam karena penipuan dengan pidana penjara paling lama empat tahun. 
Sedangkan tindak pidana penggelapan bertujuan untuk memiliki barang atau uang yang ketika itu ada dalam penguasaannya yang mana barang/uang tersebut sebenarnya adalah kepunyaan orang lain. Pelaku tindak pidana penggelapan diancam penjara maksimal empat tahun. Selengkapnya Pasal 372 KUHP berbunyi: Barang siapa dengan sengaja dan melawan hukum memiliki barang sesuatu yang seluruhnya atau sebagian adalah kepunyaan orang lain, tetapi yang ada dalam kekuasaannya bukan karena kejahatan diancam karena penggelapan, dengan pidana penjara paling lama empat tahun atau pidana denda paling banyak sembilan ratus rupiah.

Dilihat dari obyek dan tujuannya, penipuan lebih luas dari penggelapan. Jika penggelapan terbatas pada barang atau uang, penipuan termasuk juga untuk memberikan hutang maupun menghapus piutang. Dalam perkara-perkara tertentu, antara penipuan, penggelapan agak sulit dibedakan secara kasat mata. Sebagai contoh, si A hendak menjual mobil miliknya. Mengetahui hal tersebut B menyatakan kepada A bahwa ia bisa menjualkan mobil A ke pihak ketiga. Setelah A menyetujui tawaran B, kemudian ternyata mobil tersebut hilang.

Dalam kasus seperti ini, peristiwa tersebut dapat merupakan penipuan namun dapat juga merupakan penggelapan. Termasuk sebagai penipuan jika memang sejak awal B tidak berniat untuk menjualkan mobil A, namun memang hendak membawa kabur mobil tersebut. Termasuk sebagai penggelapan jika pada awalnya memang B berniat untuk melaksanakan penawarannya, namun di tengah perjalanan B berubah niat dan membawa kabur mobil A.

\subsection{Permasalahan dan Penyelesaiannya}


Kelurahan Pagambiran Ampalu NAN XX sebagai salah satu kelurahan yang ada di kecamatan Lubuk Begalung tentunya merupakan wilayah yang wajib di sentuh dengan kegiatan-kegiatan yang dapat meningkatkan kesadaran serta pengetahuan masyarakat tentang hukum, khususnya penipuan dan pengelapan.

Penipuan dan pengelapan kerap dan seri sekali terjadi dalam lingkungan kehidupan masyarakat. Penipuan dan pengelapan bukan hanya antara individuindividu dalam masyarakat akan tetapi persolan demikian juga menimpa antar keluarga. Demikian penting kesadaran hukum masyarakat maka akan membawa pengaruh besar terhadap kestabilan. Pengetahuan ini diberikan melalui kegiatan penyuluhan hukum kepada masyarakat, hal dirasakan sangat membantu pemerintah desa dalam mewujudkan masyarakat sadar hukum khususnya mengenai hukum pidana penipuan dan pengelapan.

\subsection{Metode yang digunakan}

Untuk mewujudkan program yang akan dilaksanakan maka peran pemerintah desa sangat penting, hal ini didasari lembaga-lembaga tersebut merupakan motor penggerak kemajuan dari sebuah desa. Pemerintah desa merupakan barisan terdepan berhadapan langsung dengan masyarakat yang menjalankan dan mengawal program pemerintah secara umum. Badan Permusyawaratan Desa merupakan mitra kepala desa yang dipilih oleh masyarakat mewakili unsur-unsur yang ada di masyarakat seperti unsur pemuda, tokoh agama, pendidik.

Selama pelaksanaan kegiatan pengabdian diharapkan persolan pemerintah terhadap peningkatan kesadaran hukum masyarakat dalam memahami perbedaan 
tindak pidana penipuan dan penggelapan dapat teratasi, maka indikator yang dapat di gunakan untuk mengukur keberhasilan dengan cara masyarakat dapat memahami Perbedaan Tindak Pidana Penipuan dan Penggelapan melalui peran pemerintah desa sebagai hakim desa. Keberhasilan dapat dilakukan dengan meningkatkan kemampuan sumber daya manusia, peningkatan mutu sosialisasi, sarana dan prasarana, Kepemimpinan, dan Koordinasi sangat diharapkan dalam rangka membantu mewujudkan kesadaran hukum masyarakat khususnya masyarakat Pagambiran Ampalu NAN XX dengan program pengabdian ini.

\subsection{Kelompok Sasaran, Potensi, dan Permasalahannya}

Kegiatan Pengabdian yang akan dilakukan yang bekerjasama dengan Lembaga Pemerintahan Desa bertujuan meningkatkan kesadaran hukum masyarakat terhadap perbedaan tindak pidana penipuan dan penggelapan, menitiberatkan kepada masayarakat dan tokoh masyarakat, pemuda serta pemerintah. Kelompok ini dianggap representatif dan bisa melakukan inovasi dan kontribusi positif di kelurahan.

Kelurahan Pagambiran Ampalu NAN XX cukup potensial untuk dilakukannya pengabdian ini, dalam memperhatikan peningkatan ekonomi yang semakin tinggi dan pertumbuhan penduduk yang kian banyak serta berbagai aktifitas masyarakat dan berbagai persoalan yang terjadi maka kegiatan seperti ini sangatlah bermanfaat. Masyarakat Kelurahan Pagambiran Ampalu NAN XX yang mayoritas penduduknya berpenghasilan cukup tinggi sangatlah rentan dengan permasalahan penipuan dan pengelapan. 


\section{BAB II}

\section{TARGET DAN LUARAN}

Kegiatan penyuluhan hukum yang dilakukan di Kelurahan Pagambiran Ampalu NAN XX bertujuan untuk Peningkatan Kesadaran Hukum Masyarakat dalam memahami perbedaan penipuan dan pengelapan melalui penyuluhan hukum sehingga dapat mewujudkan kesadaran hukum masyarakat. Luaran dari program ini terbagi atas dua yaitu adalah Kelurahan Pagambiran Ampalu NAN XX menjadi Keluarahan percontohan bagi dkelurahan yang lain terhadap kesadaran hukum masyarakat, dan terbentuknya kelompok-kelompok binaan yang nantinya akan menjadi wadah pengaduan masyarakat. 


\section{BAB III \\ METODE PELAKSANAAN}

\subsection{Persiapan dan Pembekalan}

1. Mekanisme pelaksanaan kegiatan pengabdian pada masyarakat meliputi tahapan berikut:

a. mengundang masyarakat yang ada di kelurahan Pagambiran Ampalu NAN XX

b. Koordinasi dengan mayarakat setempat

c. Konsultasi dengan pemerintah setempat

d. Penyiapan sarana dan prasarana terkait dengan pelaksanaan kegiatan

2. Materi persiapan mencakup:

a. Perancangan model kegiatan melalui penyuluhan hukum

b. penyampaian materi tentang undang-undang penipuan dan penggelapan

c. memahami perbedaan tindak pidana penipuan dan penggelapan

d. Kesadaran Hukum Masyarakat akan tindak pidana penipuan dan pengelapan

3. Pelaksanaan tahapan kegiatan

Dalam pelaksanaan pengabdian masyarakat ini dilaksanakan sesuai dengan jadwal pada tabel 1 dibawah ini:

Waktu Pengabdian : Agustus-Oktober 2018

Tempat Pengabdian : Kantor Lurah Pagambiran Ampalu NAN XX 
Tabel 1. Jadwal Kegiatan

\begin{tabular}{|c|c|c|c|c|c|}
\hline \multirow[t]{2}{*}{ No } & \multirow[t]{2}{*}{ Kegiatan } & \multicolumn{3}{|c|}{ Bulan } & \multirow[t]{2}{*}{ Pelaksana } \\
\hline & & Agustus & September & Oktober & \\
\hline 1 & Survey Pendahuluan & $\mathbf{V}$ & $\mathbf{V}$ & & $\begin{array}{c}\text { Tim } \\
\text { pengabdi }\end{array}$ \\
\hline 2 & $\begin{array}{l}\text { Koordinasi dengan } \\
\text { pihak } \\
\text { Kantor Lurah }\end{array}$ & $\mathbf{V}$ & $\mathbf{V}$ & & $\begin{array}{l}\text { Ketua tim } \\
\text { pengabdi }\end{array}$ \\
\hline 3 & Identifikasi masalah & & $\mathbf{V}$ & & $\begin{array}{c}\text { Tim } \\
\text { pengabdi }\end{array}$ \\
\hline 4 & Penyusunan materi & $\mathbf{V}$ & $\mathbf{V}$ & & $\begin{array}{c}\text { Tim } \\
\text { pengabdi }\end{array}$ \\
\hline 5 & Pembuatan materi & $\mathbf{V}$ & $\mathbf{V}$ & & $\begin{array}{c}\text { Tim } \\
\text { Pengabdi }\end{array}$ \\
\hline 5 & Penyuluhan & & & $\mathbf{V}$ & $\begin{array}{c}\text { Tim } \\
\text { pengabdi }\end{array}$ \\
\hline 6 & Laporan & $\mathbf{V}$ & $\mathbf{V}$ & $\mathbf{V}$ & $\begin{array}{c}\text { Tim } \\
\text { pengabdi }\end{array}$ \\
\hline
\end{tabular}

\subsection{Pelaksanaan}

Pelaksanaan pengabdian ini merupakan program penyuluhan hukum melalui perangkat kelurahan. Metode yang digunakan dalam melakukan pemberdayaan kelompok sasaran adalah pemberian materi dengan cara ceramah, diskusi dan simulasi. Langkah-langkah operasional yang diperlukan untuk mengatasi permasalahan adalah dilakukan pendampingan secara preventif untuk meningkatkan kesadaran hukum masyarakat tentang perbedaan tindak pidana penipuan dan penggelapan.

\subsection{Anggaran Biaya}

Berikut adalah rancangan anggaran biaya yang dibutuhkan untuk pelaksanan kegiatan pengabdian masyarakat ini. 


\begin{tabular}{|c|c|c|c|c|c|}
\hline No & Keterangan & Satuan & $\begin{array}{c}\text { Biaya } \\
\text { satuan } \\
(\mathbf{R p})\end{array}$ & Jumlah & $\begin{array}{c}\text { Biaya } \\
(\mathbf{R p})\end{array}$ \\
\hline & Survey & & & & \\
\hline 1 & $\begin{array}{l}\text { Bahan Bakar Survey (2 } \\
\text { kali survey @ 5 } \\
\text { liter) }\end{array}$ & Liter & $8.300,-$ & 5 & $83.000,-$ \\
\hline \multirow[t]{2}{*}{2} & $\begin{array}{l}\text { Makan Siang Survey (2 } \\
\text { kali survey @ } 3 \\
\text { orang) }\end{array}$ & Kotak & $25.000,-$ & 3 & $75.000,-$ \\
\hline & Pelaksanaan & & & & \\
\hline 1 & $\begin{array}{l}\text { Bahan Bakar Hari } \\
\text { Pelaksanaan ( } 2 \text { mobil } \\
\text { @ 5 liter) }\end{array}$ & Liter & $8.300,-$ & 5 & $83.000,-$ \\
\hline 2 & $\begin{array}{l}\text { Makan Siang Hari } \\
\text { Pelaksanaan }\end{array}$ & Kotak & $20.000,-$ & 60 & 1.200 .000 \\
\hline 3 & Snack Hari Pelaksanaan & Kotak & $8.500,-$ & 60 & $510.000,-$ \\
\hline 4 & Penggandaan Proposal & Eksamplar & $15.000,-$ & 6 & $90.000,--$ \\
\hline 5 & $\begin{array}{l}\text { Penggandaan Laporan } \\
\text { Akhir }\end{array}$ & Eksamplar & 40.000 & 6 & $240.00,-$ \\
\hline 6 & $\begin{array}{l}\text { ATK dan Fotocopy Modul } \\
\text { Pelatihan }\end{array}$ & & & & $584.000,-$ \\
\hline 7 & Sertifikat & Eksamplar & $300.000,-$ & 1 & $300.000,-$ \\
\hline \multirow[t]{2}{*}{8} & Spanduk 4x3 (12 meter) & Buah & $40.000,-$ & 1 & $480.000,-$ \\
\hline & & TOTAL & & & 3.645.000, \\
\hline
\end{tabular}




\section{BAB IV}

\section{KELAYAKAN PERGURUAN TINGGI}

Universitas Ekasakti sebagai salah satu perguruan tinggi yang ada di Provinsi Sumatera Barat tentunya ingin memberikan konstribusi positif kepada masyarakat. Sebagai wujud dari kontribusi tersebut, keberadaan Lembaga Pengabdian pada Masyarakat yang pada peran dan fungsinya adalah melaksanakan salah satu kegiatan tridharma perguruan tinggi dengan menuntut peran dosen, masyarakat, dan pemerintah untuk saling membantu dan mensinergikan program dalam memajukan bangsa dan negara. Pengabdian pada masyarakat wajib dilaksanakan oleh setiap dosen dan mahasiswa sebagai wujud tanggungjawab keilmuan yang dimilikinya.

Sebagai salah satu perguruan tinggi, Universitas Ekasakti dalam arti mencetak tenaga pendidik tentunya bertugas tidak hanya didalam lingkungan kampus saja namun harus dapat pula mengembangkan kerjasama yang erat dengan pemerintah untuk melihat dan mengkaji permasalahan yang dihadapi masyarakat. Kegiatan berupa Pengabdian yang di lakukan oleh dosen dan mahasiswa yang berupa aitem kegiatan yaitu penyuluhan hukum kepada masyarakat bertujuan untuk memberdayakan masyarakat dan memberikan pelajaran kepada mahasiswa tentang keadaan nyata yang terjadi pada masyarakat.

Tim ini akan melakukan kegiatan berupa penyuluhan hukum kepada masyarakat dan aparat desa yang ada di Desa Juriati. Penguasaan tim ini dalam melakukan kegiatan di lapangan telah banyak dibuktikan dengan berbagai kegiatan pendampingan di masyarakat yang telah banyak dilakukan. 


\section{BAB V}

\section{HASIL YANG TELAH DI CAPAI}

Mengacu pada target dan luaran serta tujuan kegiatan pengabdian ini maka dengan dilaksanakannya kegiatan pengabdian ini maka masyarakat telah memahami amanat undang-undang yang mengharuskan kepala desa menjadi hakim desa, yang awalnya tidak paham menjadi paham. Dengan metode ceramah, tanya jawab, serta pemberian contoh, maka diharapkan tujuan dari kegiatan ini tercapai. Adapun hasil yang dicapai dari pelaksanaan kegiatan ini, adalah:

1. Masyarakat Kelurahan Pagambiran Ampalu NAN XX dalam pemahan hukum tentang perbedaan tindak pidana penipuan dan penggelapan serta penyelesaianya sudah meningkat. Dengan pertanyaan-pertanyaan masyarakat saat penyuluhan hukum tersebut dapat disimpulkan bahwa masyarakat sudah pemahami prosedur penyelesaiannya.

2. Pengabdian ini bukan saja dalam bidang penyuluhan hukum saja akan tetapi kegiatan lain yang dilakukan adalah tata cara penyusunan Peraturan Desa. 


\section{BAB VI}

\section{RENCANA TAHAP BERIKUTNYA}

Rencana tahap berikutnya sebagai bentuk akhir dari pelaksanan Pengabdian ini diharapkan pemerintah dapat membentuk posko pengaduan yang dapat membantu masyarakat dalam penyelesaian setiap masalah, disamping itu untuk menindak lanjuti kegiatan yang telah dilakukan dalam rangka penyusunan peraturan desa yang berkualitas maka tahapan berikutnya berupa melakukan pendataan dan pembinaan secara intensif kepada BPD, Aparat Desa dan masyarakat. 


\section{BAB VII}

\section{KESIMPULAN DAN SARAN}

\subsection{Kesimpulan}

Pelaksanaan Pengabdian sangatlah berguna bagi pemerintah dan Masyarakat khususnya bagi masyarakat yang tidak paham terhadap prosedur penyelesaian suatu tindak pidana. Selain itu pelaksanaan Pengabdian ini dapat

meningkatkan kesadaran hukum masyarakat khususnya di Kelurahan Pagambiran ampalu NAN XX Kecamatan Lubuk Begalung

\subsection{Saran}

Atas dasar kesimpulan yang demikian itu, maka ada beberapa hal yang dapat diberikan saran atau rekomendasi, yakni sebagai berikut:

1. Pemerintah daerah bekerjasama dengan pemerintah Kecamatan melakukan penyuluhan hukum untuk meningkatkan pemahaman hukum kepada masyarakat desa.

2. Pengetahuan Kepala Kelurahan beserta aparatnya juga harus ditingkatkan melalui pembinaan-pembinaan secara rutin menyangkut persoalan hukum. 


\section{DAFTAR PUSTAKA}

\section{A. BUKU}

Abdullah Marlang, dkk. 2009. Pengantar Hukum Indonesia. AS Center, Makassar.

Achmad Ali. 2010. Menguak Teori Hukum (Legal Theory) dan Teori Peradilan (Judicialprudence). Kencana Prenada Media Grup, Jakarta.

A.S. Alam. 2010.Pengantar Kriminologi. Pustaka Refleksi, Makassar.

Asshidiqie, Jimly. 2010. Hukum Acara Pengujian Undang-Undang. Sinar Grafika. Jakarta

Panggabean, H.P. 2012. Hukum Pembuktian (Teori Praktek dan Yurisprudensi Indonesia). Alumni. Bandung.

\section{B. UNDANG-UNDANG}

Indonesia, Undang-Undang Nomor 1 Tahun 1946 tentang Kitab Undang-Undang Hukum Pidana

,Undang-Undang Nomor 8 Tahun 1981 tentang Kitab Undang-Undang Hukum Acara Pidana 